\title{
PENGEMBANGAN MODEL PELATIHAN AKUNTANSI DALAM UPAYA MENINGKATKAN KOMPETENSI KEUANGAN PADA UMKM WIRAUSAHAWAN MUDA
}

(Studi Kasus Wirausahawan Muda Mahasiswa Prodi Manajemen Bisnis Syariah IAIN KUDUS)

Ita Rakhmawati

rakhmaita@gmail.com

STAIN KUDUS

\begin{abstract}
Abstrac
Small medium enterprises is one of the perpetrators of the economic potential in Indonesia, both in terms of number and its contribution to the national economy. This event will be based on research by the large number of potential young entrepreneurs for small medium enterprises that develop among the students of business management Course Shari'a. However, the potential of encountering problems one is difficult because of the limited structure and capability still managing their finances. The purpose of this research is to know the financial competency mapping and owned by small medium enterprises run by young entrepreneur. Further based on the database used to compile the proper accounting training design. Primary data obtained from in-depth interviews, questionnaires and observation directly. Financial competence that is owned by young entrepreneurs for small medium enterprises can be seen from the source variable capitalization, turnover, business profits and the ability of the application of accounting in the form of presentation of the financial statements. The results showed that most small medium enterprises have difficulty in the sector as well as a good amount of capitalization capital structure. small medium enterprises operational views of the turnover and operating income showed a fairly progressive conditions for businessmen beginners. While the ability of drawing up financial statements still minimal, more that just make a simple cash flow report.
\end{abstract}

Keyword: Small Medium Enterprises, Accounting Training 


\section{A. PENDAHULUAN}

UMKM adalah salah satu sektor perekonomian yang memegang peranan yang cukup potensial. Sesuai teori J. Schumpeter yang menyatakan pertumbuhan ekonomi suatu negara akan berbanding lurus dengan jumlah dan inovasi wirausahawan yang ada di dalamnya. Keberadaan UMKM diberbagai sektor usaha mampu mengurangi pengangguran dan membuka lapangan pekerjaan baru. Keberadaan UMKM secara riil juga turut andil dalam meningkatkan pendapatan nasional. UMKM merupakan sektor usaha yang paling banyak memberikan kontribusi terhadap perekonomian di Indonesia. Data Bappenas menunjukkan jumlah UMKM di Indonesia pada tahun 2013 mencapai lebih 57,8 juta unit. Dari jumlah tersebut sebagian besar termasuk dalam skala mikro. Keberadaan UMKM ampuh menyerap tenaga kerja sebanyak 114,1 juta tenaga kerja dan pertumbuhan sumbangan PDB sebesar 5,89\%.

Menurut Peraturan Pemerintah No. 41 tahun 2011 tentang Pengembangan Kewirausahaan dan Kepeloporan Pemuda serta Penyediaan Prasarana dan Sarana Kepemudaan menjelaskan pemuda adalah warga negara Indonesia yang memasuki periode penting pertumbuhan dan perkembangan yang berusia mulai dari enam belas tahun hingga tiga puluh tahun. Masih dalam peraturan yang sama pengembangan kewirausahaan pemuda adalah adalah kegiatan mengembangkan potensi ketrampilan dan kemandirian berusaha. Sedangkan dalam Undang Undang No 40 tahun 2009 tentang Kepemudaan bahwa pemberdayaan pemuda salah satunya bisa dilakukan melalui peneguhan kemandirian ekonomi pemuda.

Pemuda sebagai generasi penerus bangsa harus memiliki kesiapan lebih dini dalam menghadapi berbagai persoalan di era desrupsi. Sebuah situasi dimana kondisi sosial ekonomi berubah dan melenceng jauh dari akar yang selama ini telah tertanam dalam. Kenyataan di lapangan membuktikan, banyak UMKM yang dikelola oleh wirausaha muda terbukti mampu melesat jauh dari para seniornya. Sebagai contoh keberadaan Waroeng SS yang dikelola Yoyok Hery Wahyono 
yang saat ini mampu meraih omzet hingga 12 Milyar tiap bulannya. Victor Giovan Raihan seorang pemuda yang memulai usaha "Teh Kempot" mampu membawanya menjadi young entrepreneur dengan puluhan outlet yang dimiliki. Pada ruang lingkup yang lebih kecil UMKM yang dikelola oleh wirausaha muda khususnya mahasiswa Manajemen Bisnis Syariah merupakan forum pengaplikasian ilmu dan teori yang didapatkan di bangku perguruan tinggi.

Sebagai salah satu sektor yang potensial, keberadaan UMKM terutama yang dikelola oleh wirausahawan muda harus mendapatkan perhatian lebih dari stakeholder. Hal ini dalam rangka meningkatkan potensi dan kemampuannya sehingga mampu meningkatkan bergaining position dalam rangka menghadapi arus global market yang semakin deras. Salah satu keunggulan UMKM yang dikelola oleh young entrepreneur adalah lebih banyak memperhatikan aspek teknologi dan kreativitas yang tidak ada hentinya. Hal ini sangat tepat sekali dalam menghadapi kondisi pasar yang dinamis. Upaya pengembangan potensi UMKM oleh wirausahan muda harus terus ditingkatkan tidak hanya pada aspek produksi, pemasaran maupun manajemen semata namun juga aspek keuangan. Kemampuan pengelolaan keuangan yang dibuktikan dengan financial report juga merupakan salah satu kunci sukses dalam mengelola UMKM. Hal ini salah satunya agar akses UMKM terhadap berbagai eksternal stakeholder seperti perbankan, pemerintah, investor dan juga mitra kerja lebih terbuka. Financial report yang dapat diakses secara umum mampu meningkatkan akuntabilitas perusahaan. Hal ini akan terwujud jika pelaku UMKM terutama wirausahaan muda memiliki kemampuan literasi keuangan yang sesuai.

Kurniawati et al (2012) menjelaskan bahwa penerapan akuntansi usaha kecil terutama usaha dagang masih sangat rendah karena kendala faktor pendidikan yang rendah termasuk dalam pengetahuan akuntansi dan kurangnya kesadaran akan pentingnya akuntansi. Sedangkan penelitian yang dilakukan oleh Wafirotin (2016) menyebutkan lebih dari 50\% UMKM mengalami kesulitan di sektor permodalan. 
Penelitian ini diharapkan akan mampu memberikan gambaran riil terkait kompetensi keuangan para pelaku UMKM wirausahawan muda dari kalangan mahasiswa. Berdasarkan hasil penelitian tersebut diharapkan dapat diketahui potensi dan juga kelemahan yang dihadapi sehingga dapat dikembangkan model pelatihan akuntansi yang cocok sesuai kebutuhan yang mampu meningkatkan kompetensi keuangan bagi pelaku wirausaha muda. Dengan meningkatnya kompetensi keuangan UMKM wirausaha muda diharapkan dalam ruang lingkup mikro dapat meningkatkan bargaining position UMKM tersebut dan dalam ruang lingkup makro mampu mengembangkan perekonomian nasional.

\section{B. PEMBAHASAN}

\section{Landasan Teori}

\section{a. UMKM}

Berdasarkan Undang-Undang Nomor 20 Tahun 2008 tentang Usaha Mikro, Kecil dan Menengah (UMKM), UMKM adalah usaha ekonomi produktif, yang berdiri sendiri yang dilakukan oleh orang perorang atau badan usaha yang bukan merupakan anak perusahaan atau cabang perusahaan yang dimiliki, dikuasai atau menjadi bagian langsung maupun tidak langsung dengan usaha kecil atau usaha besar dengan jumlah kekayaan bersih atau hasil penjualan tahunan sebagaimana diatur dalam undang undang. Salah satu kriteria yang digunakan untuk mengelompokkan sektor UMKM adalah besarnya omzet yang di dapatkan dalam satu periode serta jumlah aset yang dimiliki. Berikut adalah kriteria UMKM dilihat dari besarnya aset yang dimiliki dan omzet yang didapatkan:

Tabel. 1

Kriteria UMKM

\begin{tabular}{|l|l|l|l|}
\hline \multirow{2}{*}{ No } & \multirow{2}{*}{$\begin{array}{c}\text { Jenis Sektor } \\
\text { Usaha }\end{array}$} & \multicolumn{1}{|c|}{ Indikator } \\
\cline { 3 - 4 } & \multicolumn{1}{|c|}{ Omzet per periode } & \multicolumn{1}{c|}{ Besar aset } \\
\hline 1 & Usaha mikro & s/d Rp. 300juta & s/d 50 juta \\
\hline 2 & Usaha kecil & 300 juta $-2,5$ Milyar & $50 j u t a-500$ juta \\
\hline 3 & Usaha Menengah & 2,5 Milyar -50 Milyar & 500 juta $-10 \mathrm{M}$ \\
\hline
\end{tabular}

Sumber : UU No. 20 Tahun 2008, Tentang UMKM 
Keberadaan UMKM yang besar di masyarakat, diharapkan mampu menjadi motor penggerak perekonomian. UMKM merupakan sektor yang paling banyak bersentuhan dengan masyarakat secara langsung. Upaya pemberdayaan UMKM perlu dilakukan dalam rangka pengembangan UMKM agar menjadi unit usaha yang maju, mandiri, dan berdaya saing. Menurut UU No. 20 tahun 2008 Prinsip pemberdayaan usaha mikro, kecil dan menengah adalah :

1. Penumbuhan kemandirian, kebersamaan, dan kewirausahaan usaha mikro, kecil dan menengah untuk berkarya dengan prakarsa sendiri.

2. Perwujudan kebijakan publik yang transparan, akuntabel, dan berkeadilan.

3. Pengembangan usaha berbasis potensi daerah dan beorientasi pasar sesuai dengan kompetensi usaha mikro, kecil dan menengah.

4. Peningkatan daya saing usaha mikro, kecil dan menengah

5. Penyelenggaraan, perencanaan, pelaksanaan dan pengendalian mutu terpadu.

Upaya pemberdayaan UMKM urgent untuk dilakukan mulai dari sedini mungkin. Pemberdayaan UMKM merupakan suatu upaya yang dilakukan oleh pemerintah, pemerintah daerah, dunia usaha dan masyarakat secara sinergis dalam bentuk penumbuhan iklim dan pengembangan usaha terhadap usaha mikro, kecil dan menengah sehingga mampu tumbuh dan berkembang menjadi usaha yang tangguh dan mandiri.

Pemerintah maupun Pemerintah Daerah dengan peraturan perundang undangan dan kebijakannya berusaha untuk menumbuhkan iklim usaha yang tepat bagi UMKM termasuk dalam sektor pendanaan. Komitmen pemerintah tersebut ditunjukkan dengan memberikan kemudahan bagi UMKM untuk mengakses kredit perbankan dan lembaga keuangan bukan bank baik dengan sistem konvensional maupun dengan sistem syari'ah.

\section{b. Kompetensi Keuangan}

Pengelolaan keuangan merupakan salah satu aspek dalam pengelolaan UMKM yang sering terabaikan. Hal ini dapat disebabkan salah satunya karena minimnya kompetensi keuangan pelaku UMKM tersebut. Kompetensi keuangan UMKM dapat dilihat dari aspek permodalan, volume penjualan, laba operasional yang dapat ditunjukkan dari laporan keuangan yang dihasilkan. 
Permodalan merupakan salah satu aspek dalam bisnis yang memiliki peran penting. Modal kerja sendiri dapat diartikan sebagai sejumlah dana untuk membiayai operasional perusahaan sehari hari dalam rangka mencari keuntungan. Disisi lain modal kerja dapat juga diartikan sebagai kelebihan asset lancer atas utang jangka pendek yang dimiliki perusahaan. Struktur modal ini dapat bersumber dari intern maupun ekstern. Semakin besar proporsi modal ekstern akan menyebabkan nilai perusahaan akan mengalami penurunan.

Volume penjualan merupakan ukuran untuk menunjukkan kapasitas atau kemampuan perusahaan dalam melayani pelanggan. Volume penjualan menunjukkan total barang atau jasa yang diserahkan kepada pelanggan selama satu periode. Periode perhitungan penjualan pada umumnya bulanan atau tahunan. Penjualan yang diterima berasal dari total penjualan baik yang bersifat tunai maupun penjualan dengan sistem kredit.

Laba usaha secara umum merupakan tujuan utama dari setiap badan usaha. Laba sendiri merupakan merupakan ukuran yang menujukkan kinerja keuangan UMKM yang berasal dari operasional usaha perusahaan sehari hari dengan memanfaatkan segala sumber daya yang dimiliki. Laba dihitung berdasarkan besarnya kelebihan penghasilan diatas biaya yang dikeluarkan selama satu periode akuntansi. Kemampuan perusahaan dalam mendapatkan laba disebut dengan profitabilitas yang dapat diukur dengan berbagai rasio sesuai dengan sudut pandang masing masing. Semakin besar profitabilitas semakin besar laba yang dihasilkan dan berarti semakin baik pula kinerja keuangan entitas tersebut.

Laporan keuangan (financial statement) merupakan output utama dari pelaksanaan sistem akuntansi selama satu periode di setiap entitas. Laporan keuangan yang reliable dihasilkan jika proses akuntansi selama satu periode dilaksanakan secara tepat. Kelalaian dalam setiap tahap akuntansi menjadikan laporan keuangan yang dihasilkan akan bias dan tidak dapat dihandalkan. Laporan keuangan merupakan sumber informasi dalam rangka pengambilan keputusan oleh para stakeholder. Laporan keuangan yang disajikan perusahaan untuk kepentingan pihak ekstern menurut PSAK adalah meliputi laporan laba rugi, laporan perubahan ekuitas, laporan posisi keuangan, laporan arus kas dan juga catatan atas laporan keuangan. 
Pelaku UMKM masih terbatas pengetahuannya terkait proses pencatatan akuntansi dalam usaha yang dijalankan, oleh sebab itu kelayakan usaha UMKM dari aspek keuangan masih sangat terbatas (Bank Indonesia, 2005). Hal tersebut dapat menjadi salah satu mata peluru untuk meningkatkan kompetensi UMKM secara umum

\section{c. Akuntansi}

Akuntansi biasa disebut dengan language of business atau bahasa bisnis. Hal ini karena dengan akuntansi, segala informasi yang bersifat keuangan dapat dikomunikasikan dengan baik. Secara umum akuntansi adalah proses untuk mengidentifikasikan seluruh data transaksi keuangan agar dapat menghasilkan informasi keuangan yang penting sebagai dasar dalam pengambilan keputusan. Menurut Yusuf (2012), Akuntansi adalah sistem informasi yang mengukur aktivitas bisnis, mengolah data menjadi laporan dan mengkomunikasikan hasilnya kepada para pengambil keputusan. Output dari proses akuntansi menghasilkan laporan keuangan yang meliputi laporan laba rugi, laporan perubahan ekuitas, laporan neraca, laporan arus kas dan catatan atas laporan keuangan.

\section{Kerangka Pikir}

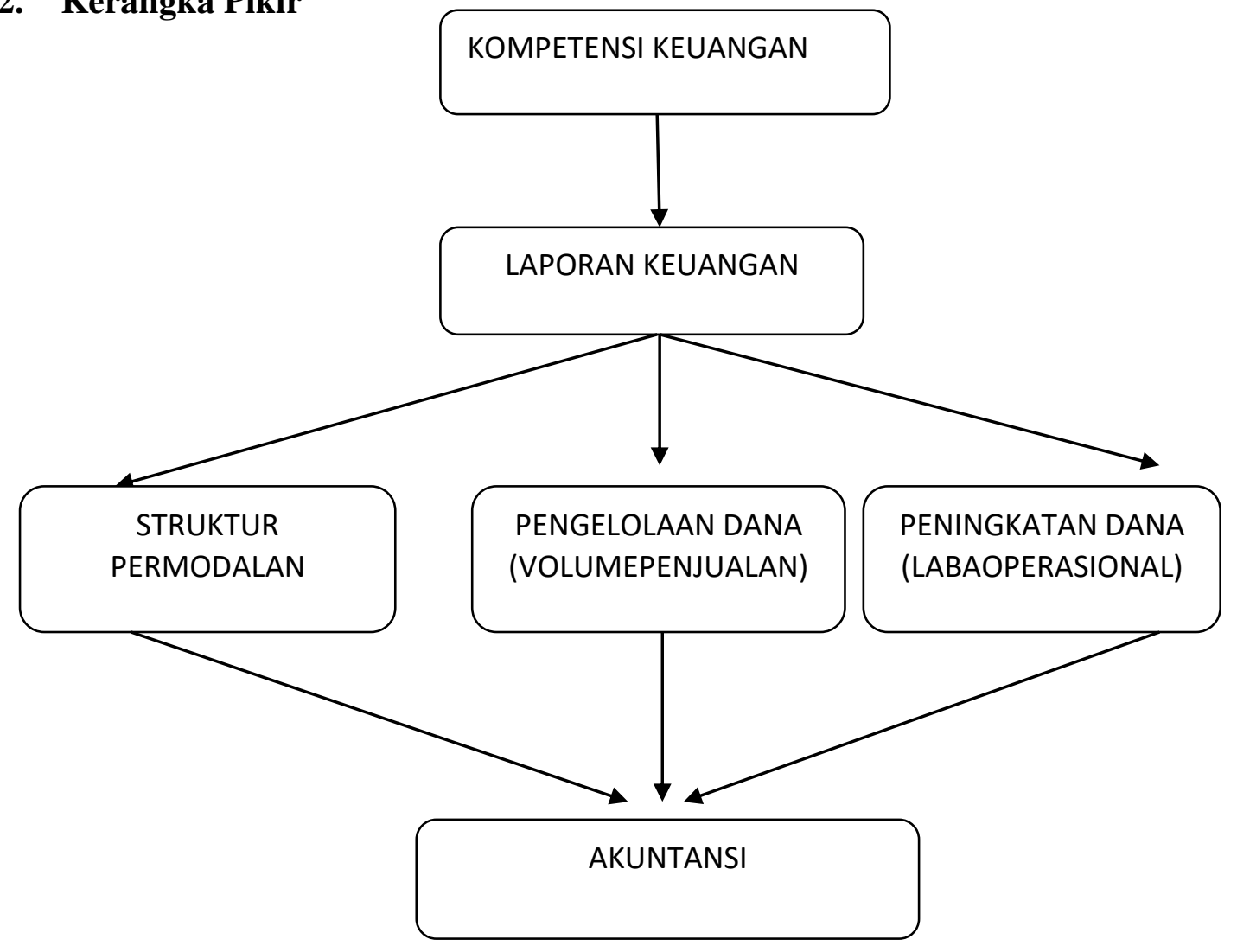




\section{METODE PENELITIAN}

\section{Ruang Lingkup dan Objek Penelitian}

Ruang lingkup penelitian ini berada di wilayah Kabupaten Kudus. Sampling dilakukan dengan metode purposive sampling yaitu sampel bertujuan yaitu pengambilan sampel dengan memenuhi kriteria tertentu dalam rangka mencapai tujuan. Dalam hal ini adalah sampel adalah pelaku UMKM wirausahawan muda yang berasal dari kalangan mahasiswa Program Studi Manajemen Bisnis Syaiah IAIN yang saat terjadinya penelitian sedang dan masih menjalankan usaha pada berbagai sektor ekonomi. Sampel penilitian ini terdiri dari 35 pelaku wirausahawan muda.

\section{Jenis Data dan Metode Pengumpulan Data}

Jenis penelitian ini adalah diskriptif kuantitatif, yaitu salah satu jenis penelitian yang menyajikan gambaran secara lengkap gambaran mengenai objek penelitian. Data yang digunakan dalam penelitian ini adalah data primer dan data sekunder. Data primer diperoleh melalui metode wawancara langsung dengan pelaku UMKM wirausahan muda dan dibantu dengan kuesioner. Sedangkan data sekunder diperoleh melalui berbagai sumber resmi.

\section{HASIL PENELITIAN}

\section{Data Deskriptif Lapangan}

Berdasarkan hasil analisis data menunjukkan pelaku UMKM wirausaha muda mahasisiwa IAIN Kudus, lebih didominasi oleh kaum perempuan dibandingkan laki laki dengan persentase $66 \%$. Hal tersebut diperlihatkan dengan data sebagai berikut: 
Tabel. 2

Distribusi Pelaku UMKM

\begin{tabular}{|c|c|c|c|}
\hline No & Pelaku Usaha & Jumlah & Presetase \\
\hline 1 & Laki Laki & 12 & $34 \%$ \\
\hline 2 & perempuan & 23 & $66 \%$ \\
\hline & Jumlah & 35 & $100 \%$ \\
\hline
\end{tabular}

Sumber: Data primer diolah, 2018

Selain karena memang secara demografis, struktur penduduk Indonesia yang menunjukkan dominasi jumlah perempuan dibandingkan dengan laki laki hal tersebut juga dipengaruhi oleh perempuan yang lebih bersifat multitasking dibandingkan laki laki. Mahasiswa perempuan lebih mampu menjalankan dua kegiatan yaitu mengikuti perkuliahan dan juga menjalankan bisnisnya secara bersamaan dari pada mahasiswa laki laki pada umumnya.

Berdasarkan bidang usaha yang ditekuni, sebagian besar pelaku UMKM wirausaha muda lebih banyak bergerak pada sektor perdagangan dengan persentase sebesar $51 \%$. Hal tersebut ditunjukkan dengan data sebagai berikut:

Tabel. 3

Bidang Usaha UMKM

\begin{tabular}{|c|c|c|c|}
\hline No & Bidang Usaha & Jumlah & Presentase \\
\hline 1 & Jasa & 10 & $29 \%$ \\
\hline 2 & Dagang & 18 & $51 \%$ \\
\hline 3 & Manufaktur & 7 & $20 \%$ \\
\hline & Jumlah & 35 & $100 \%$ \\
\hline
\end{tabular}

Sumber: Data primer diolah, 2018

Usaha dagang merupakan jenis usaha dengan kegiatan utama membeli barang untuk dijual kembali tanpa merubah bentuk. Hal tersebut banyak dijadikan pilihan mengingat keberadaan UMKM tersebut memang dikelola mahasiswa yang fokus perhatiaannya masih pada pendidikan. Dagang diyakini oleh pelaku usaha 
pengelolaannya lebih mudah dibandingkan sektor jasa maupun manufaktur. Meskipun demikian salah satu kendala yang dihadapi pada usaha datang adalah tersendatnya pasokan barang dagang jika pelaku tidak memiliki jumlah supplier yang memadai.

Berdasarkan periode lama UMKM berdiri, rata rata masih dalam tahap awal atau rinntisan dengan periode yang belum mencapai satu tahun berjalan. Hal tersebut ditunjukkan dengan data sebagai berikut:

Tabel. 4

Usia UMKM

\begin{tabular}{|l|l|r|r|}
\hline No & \multicolumn{1}{|c|}{ Umur Usaha } & \multicolumn{1}{|c|}{ Jumlah } & \multicolumn{1}{c|}{ Presentase } \\
\hline 1 & Kurang dari 1 tahun & 15 & $43 \%$ \\
\hline 2 & $1 \mathrm{~s} / \mathrm{d} 3$ tahun & 13 & $37 \%$ \\
\hline 3 & $3 \mathrm{~s} / \mathrm{d} 5$ tahun & 6 & $17 \%$ \\
\hline 4 & lebih dari 5 tahun & 1 & $3 \%$ \\
\hline & & & $100 \%$ \\
\hline \multicolumn{2}{|c|}{ jumlah }
\end{tabular}

Sumber: Data primer diolah, 2018

Mengingat masih dalam fase awal, UMKM perlu banyak untuk belajar dan memperkuat kemampuan diri baik dalam manajemen maupun keuangan. Materi dari perkuliahan, seminar, workshop dan juga tergabung dalam KOPMA diakui dapat menambah kemampuan dalam menjalankan bisnis.

\section{Analisis}

Penelitian ini menggunakan empat variabel dalam rangka mengungkapkan kompetensi keuangan sektor UMKM. Keempat variabel tersebut meliputi sektor permodalan, volume penjualan, tingkat laba, kemampuan menyusun laporan keuangan. Diharapkan dengan diungkapkannya keempat variabel tersebut dapat diketahui kondisi keuangan UMKM, kelebihan dan kekurangannya. Sebagai tindak lanjut diharapkan pada tahap berikutnya penelitian ini dapat berlanjut pada pemberian pelatihan keuangan pada UMKM agar lebih berdaya saing. 
a) Permodalan

Setiap sektor usaha membutuhkan sejumlah modal dalam rangka operasional perusahaan. Secara umum modal adalah setoran oleh investor. Modal kerja didefinisikan sebagai modal kerja kotor dan modal kerja bersih. Modal kerja kotor identik dengan seluruh nilai dari aset lancar, baik berupa kas, piutang, persediaan, pelengkapan dan aset lancar lainnya. Sedangkan modal kerja bersih mengacu pada nilai dari total aset lancar dikurangi dengan kewajiban lancar perusahaan kepada pihak lain. Sektor permodalan diungkap dari besar kecilnya sumber permodalan dan jumlah modal. Dilihat dari sumber permodalan, wirausahan muda pelaku UMKM sebagian besar atau 57\% sumber permodalan berasal dari modal sendiri. Hal tersebut ditunjukkan data sebagai berikut:

Tabel. 5

Sumber Permodalan UMKM

\begin{tabular}{|l|l|r|r|}
\hline No & \multicolumn{1}{|c|}{ Sumber Permodalan } & Jumlah & Presentase \\
\hline 1 & modal sendiri & 20 & $57 \%$ \\
\hline 2 & Pinjaman pihak lain non lembaga keuangan & 13 & $37 \%$ \\
\hline 3 & pinjaman pihak lain lembaga keuangan & 1 & $3 \%$ \\
\hline 4 & hibah & 1 & $3 \%$ \\
\hline & Jumlah & 35 & $100 \%$ \\
\hline \multicolumn{2}{|c|}{} \\
\hline
\end{tabular}

Sumber: Data primer diolah, 2018

Sedangkan dilihat dari jumlah permodalan, mencapai $86 \%$ jumlah modal yang dimiliki UMKM ini masih berkisar pada angka dibawah Rp. 10.000.000,00. Hal tersebut ditunjukkan oleh data sebagai berikut:

Tabel. 6

Jumlah Permodalan UMKM

\begin{tabular}{|l|l|r|r|}
\hline No & \multicolumn{1}{|c|}{ jumlah Permodalan } & Jumlah & Presentase \\
\hline 1 & kurang dari Rp. 10.000.000,00 & 30 & $86 \%$ \\
\hline 2 & Rp. 10.000.000,00 S/ D Rp. 100.000.000,000 & 3 & $9 \%$ \\
\hline 3 & lebih dari Rp. 100.000.000,00 & 2 & $6 \%$ \\
\hline & Jumlah & & $100 \%$ \\
\hline
\end{tabular}

Sumber: Data primer diolah, 2018 
Berdasarkan data tersebut UMKM yang dikelola oleh wirausaha muda sebagaian besar masih memiliki kesulitan pada sektor sumber dan jumlah permodalan yang dimiliki. Sumber permodalan lebih cenderung mengandalkan pada modal sendiri sehingga jumlah yang tersedia masih sangat terbatas. Hal ini dikarenakan sebagai usaha rintisan, UMKM belum banyak memiliki akses terhadap sumber permodalan lain baik dari lembaga keuangan ataupun lembaga non keuangan. Sehingga kebutuhan modal dipenuhi dari modal sendiri yang jumlahnya masih terbatas. Pengelolaan dan pelaporan keuangan yang baik diharapkan mampu menjadikan UMKM sebagai entitas yang bankable. Stimulan stimulan keuangan dari pemerintah baik berupa bantuan usaha maupun kredit bergulir juga diharapkan dapat menyentuh pelaku usaha kecil.

b) Penjualan

Berdasarkan hasil penelitian menujukkan bahwa omzet penjualan UMKM oleh wirausahawan muda per tahun terlihat seperti tabel berikut:

Tabel. 7

Volume Penjualan UMKM

\begin{tabular}{|c|c|c|c|}
\hline . No & Volume Penjualan & Jumlah & Presentase \\
\hline 1 & kurang dari Rp. $100.000 .000,00$ & 33 & $94 \%$ \\
\hline 2 & $\begin{array}{l}\text { Rp. } 100.000 .000,00 \text { S/ D Rp. } \\
200.000 .000,000\end{array}$ & 2 & $6 \%$ \\
\hline 3 & lebih dari Rp. 200.000.000,00 & 0 & $0 \%$ \\
\hline & Jumlah & 35 & $100 \%$ \\
\hline
\end{tabular}

Sumber: Data primer diolah, 2018

Dari data tersebut menunjukkan bahwa sebagian besar atau 94\% dari UMKM wirausaha muda memiliki omzet penjualan kurang dari Rp 100.000.000,00. Omzet tersebut baik berasal dari transaksi yang bersifat tunai maupun kredit. Sebagian dari transaksi adalah transaksi penjualan berdasarkan pesanan terlebih dahulu (by order).

Meskipun masih dalam rentang yang kecil, tapi diakui oleh pelaku usaha omzet penjualan yang mereka dapatkan banyak mengalami pertumbuhan yang 
cukup progresif. Hal ini mampu memberikan semangat baru bagi pelaku untuk lebih berkembang dengan cara berupaya untuk melakukan inovasi.

c) Penghasilan bersih

Penghasilan bersih di dapatkan dari persentase penghasilan bersih terhadap besarnya modal kerja yang digunakan. Berdasarkan hasil penelitian menujukkan bahwa penghasilan bersih UMKM oleh wirausahawan muda per tahun terlihat seperti tabel berikut:

Tabel. 8

Persentase Laba Bersih dari Modal UMKM

\begin{tabular}{|l|l|r|r|}
\hline No & \multicolumn{1}{|c|}{ Persentase laba bersih dari modal } & Jumlah & Presentase \\
\hline 1 & kurang dari 30\% & 25 & $71 \%$ \\
\hline 2 & 30 S/ D 50\% & 7 & $20 \%$ \\
\hline 3 & lebih dari 50\% & 3 & $9 \%$ \\
\hline & Jumlah & 35 & $100 \%$ \\
\hline
\end{tabular}

Sumber: Data primer diolah, 2018

Dari data tersebut menunjukkan bahwa sebagian besar yaitu $71 \%$ dari UMKM wirausaha muda memiliki persentase laba bersih dari laba kurang dari $30 \%$. Secara sederhana tingkat pengembalian atas modal (return on investment) masih mencapai 30\%. Hal ini menunjukkan usaha yang sedang dijalankan layak untuk dipertahankan dan ditingkatkan.

d) Penyusunan laporan keuangan

Berdasarkan hasil penelitian menunjukkan bahwa kemampuan menyajikan laporan keuangan para pelaku UMKM wirausahawan muda ditunjukkan oleh data sebagai berikut: 
Tabel. 9

Penyusunan Laporan Keuangan UMKM

\begin{tabular}{|r|l|r|r|}
\hline \multicolumn{1}{|c|}{ No } & Penyusunan laporan keuangan & Jumlah & Presentase \\
\hline 1 & Rutin & 14 & $40 \%$ \\
\hline 2 & Kadang kadang & 20 & $57 \%$ \\
\hline 3 & Tidak pernah & 1 & $3 \%$ \\
\hline & jumlah & 35 & $100 \%$ \\
\hline \multicolumn{2}{|c|}{} \\
\hline
\end{tabular}

Sumber: Data primer diolah, 2018

Laporan keuangan merupakan output dari proses akuntansi yang dilakukan selama satu periode keuangan. Laporan keuangan memiliki fungsi sebagai media komunikasi bisnis antara perusahaan dengan stakeholder eksternal lainnya. Berdasarkan laporan keuangan yang dihasilkan banyak keputusan keputusan bisnis diambil. Mengingat pentingnya laporan keuangan, perusahaan diharapkan mampu menyajikan laporan tersebut sesuai dengan standart akuantansi yang berlaku. Namun, kenyataan di lapangan menunjukkan Pelaku UMKM masih terbatas pengetahuannya terkait proses pencatatan akuntansi dalam usaha yang dijalankan. UMKM hanya menjalankan sebagian dari proses akuntansi. UMKM pada umumnya hanya mampu membuat pencatatan aliran kas masuk dan aliran kas keluar, penjualan, dan pembelian.

Melihat hasil penelitian yang demikian dapat disimpulkan bahwa penerapan akuntansi pada UMKM terutama yang dikelola oleh wirausaha muda masih sangat minim. Terdapat berbagai kendala yang dihadapi pelaku antara lain minimnya pengetahuan yang dimiliki, keterbatas waktu, minimnya kesadaran pelaku dan juga asumsi penerapan akuntansi akan meningkatkan biaya operasional perusahaan. Namun demikian harapan UMKM untuk dapat menerapkan akuntansi dalam unit usaha yang dikelolanya juga sangat tinggi karena di dorong oleh keinginan untuk mengembangkan usaha yang digelutinya menjadi lebih professional. Salah satu bentuk riilnya adalah harapan untuk dapat mengakses kemitraan terhadap pihak luar terutama dalam bidang permodalan baik itu dengan lembaga keuangan perbankan maupun pemerintah. 


\section{E. PENUTUP}

\section{Kesimpulan}

1. Potensi UMKM yang dikelola oleh wirausaha muda sangat besar baik dari segi jumlah maupun kapasitasnya, sehingga patut untuk mendapat perhatian dalam rangka meningkatkan pemberdayaan dan kemitraan antarUMKM.

2. Kompetensi keuangan UMKM wirausaha muda dilihat dari aspek permodalan, penjualan, laba usaha dan kemampuan menyusun laporan keuangan masih sangat terbatas sehingga memerlukan upaya peningkatan kompetensi keuangan.

3. Upaya meningkatkan kompetansi keuangan salah satunya dapat dilakukan melalui pelatihan akuntansi yang tepat guna.

\section{Saran}

1. Diperlukannya sebuah wadah bersama untuk mengakomodir dan membangun jaring kemitraan antarUMKM agar lebih kuat dalam pengelolaan dan posisi tawarnya.

2. Pemerintah diharapkan menyediakan berbagai affirmative policy terhadap perkembangan UMKM oleh pelaku wirausahawan muda.

\section{DAFTAR PUSTAKA}

Bank Indonesia. 2005. Kajian Mengenai Rumusan Standar Minimum Laporan Keuangan Dan Business Plan Untuk Umkm-Persiapan Bank Indonesia Dalam Menghadapi Masyarakat Ekonomi Asean 2015. Jakarta

Kurniawati, Elisabeth Penti, Paskah Ika Nugroho, Dan Diyan Setyawati. 2012. Penerapan Akuntansi Untuk Usahakecil Dan Menengah (Ukm) Studi Kasus Pada Usaha Dagang Kota Salatiga. Jurnal Manajemen Keuangan. 10, (2), 1 -10 .

Peraturan Pemerintah Republik Indonesia Nomor 41 Tahun 2011 Tentang Pengembangan Kewirausahaan Dan Kepeloporan Pemuda, Serta Penyediaan Prasarana Dan Sarana Kepemudaan

Tabel Perkembangan Umkm Tahun 1997 - 2013. Diperoleh 5 Juni 2018 Dari https://Www.Bappenas.Go.Id. 
Undang - Undang Republik Indonesia No. 20 Tahun 2008 Tentang Usaha Mikro, Kecil Dan Menengah

Undang - Undang Republik Indonesia Nomor 40 Tahun 20092009 Tentang Kepemudaan

Yusuf, Al Haryono, 2012. Dasar Dasar Akuntansi, STIE YKPN: Yogyakarta

Wafirotin, Dan Sumarsono. Pengembangan Model Pelatihan Akuntansi Dalam Upaya Peningkatan Kompetensi Keuangan Pada Pelaku Usaha Mikro,Kecil Dan Menengah (Umkm) Di Ponorogo Diakses 5 Juni 2018 Dari ://Eprints.Umpo.Ac.Id/2744/ 